\title{
Anti-CCR4 antibody activates virus specific immune response in STLV-1 infected Japanese monkey
}

\author{
Kenji Sugata', Jun-ichirou Yasunaga ${ }^{1}$, Kisato Nosaka ${ }^{2}$, Masao Matsuoka ${ }^{1 *}$ \\ From 17th International Conference on Human Retroviruses: HTLV and Related Viruses \\ Trois llets, Martinique. 18-21 June 2015
}

Transgenic mouse model is useful to study pathogenesis of viral genes like tax and HBZ. However, it is impossible to study the host immune responses by these transgenic mice. We used simian T-cell leukemia virus type 1 (STLV-1) infected Japanese monkeys (JMs) to analyze host immune responses after treatment by anti-CCR4 monoclonal antibody (mAb). In the previous study, we reported that anti-CCR4 mAb treatment in STLV-1 infected JMs significantly reduced CCR4 positive cells and STLV-1 proviral load (PVL). In this study, we investigated the long-term effect (48 weeks) on PVL and immune responses to STLV-1 Tax (sTax) and bZIP factor (SBZ) after the anti-CCR4 mAb treatment. STLV-1 PVL in the JMs was kept at the lower level than 0 week even 48 weeks later. To further investigate the antiCCR4 mAb induced antiviral effect, we analyzed regulatory $\mathrm{T}$ (Treg) cells and sTax and SBZ specific T-cell responses. Treg cells, which were CCR4 positive, were rapidly reduced after the treatment. The number of activated Treg cells (most functional population) was severely suppressed. Furthermore, anti-CCR4 mAb treatment of infected CD4 T cells from the JMs enhanced engulfment by phagocytes, which likely enhances antigen-presentation. Treated JMs showed spontaneous activation of cytotoxic T-lymphocytes (CTLs) to sTax and SBZ. However, the immune response to other antigen was not enhanced. In consistent with these data, the enhanced T-cell responses (anti-Tax and HBZ) were also observed in anti-CCR4 mAb treated ATL patients. Taken together, anti-CCR4 mAb induces CTLs to sTax/Tax and HBZ/SBZ by two different mechanisms: reduced Treg

\footnotetext{
* Correspondence: mmatsuok@virus.kyoto-u.ac.jp

'Laboratory of Virus Control, Institute for Virus Research, Kyoto University, Kyoto, Japan

Full list of author information is available at the end of the article
}

cells and enhanced antigen presentation by antibodydependent cell-mediated phagocytosis. These effects of anti-CCR4 $\mathrm{mAb}$ induce prolonged suppression of PVL, which might enable long-term control of ATL and HTLV-1 infected cells.

\section{Authors' details}

${ }^{1}$ Laboratory of Virus Control, Institute for Virus Research, Kyoto University, Kyoto, Japan. ${ }^{2}$ Department of Hematology, Kumamoto University School of Medicine, Kumamoto, Japan.

Published: 28 August 2015

doi:10.1186/1742-4690-12-S1-041

Cite this article as: Sugata et al: Anti-CCR4 antibody activates virus specific immune response in STLV-1 infected Japanese monkey. Retrovirology 2015 12(Suppl 1):O41.

Submit your next manuscript to BioMed Central and take full advantage of:

- Convenient online submission

- Thorough peer review

- No space constraints or color figure charges

- Immediate publication on acceptance

- Inclusion in PubMed, CAS, Scopus and Google Scholar

- Research which is freely available for redistribution

Submit your manuscript at www.biomedcentral.com/submit

\section{() Biomed Central}

